\title{
Short Films in the EFL Classroom: Creating Resources for Teachers and Learners
}

\author{
Paikar Fatima Mazhar Hameed \\ College of Science and Arts, Methnab, Qassim University, Saudi Arabia \\ E-mail: fatima.paiker8989@gmail.com
}

Received: 05-10-2015

Published: 01-03-2016
Accepted: 03-01-2016

doi:10.7575/aiac.ijalel.v.5n.2p.215
Advance Access Published: January 2016

URL: http://dx.doi.org/10.7575/aiac.ijalel.v.5n.2p.215

\begin{abstract}
This study aims to promote the use of films in learning English language in Qassim University, Saudi Arabia. It also tends to explore whether or not the inappropriate use of media like computers and mobiles is the cause behind the learners' low level of proficiency in English. Further, it will shed light on the importance of using multimedia in creating a collaborative and more meaningful learning environment. With the growing use of ICT in education, pedagogies the world over have become more learner centered and function oriented. In Saudi Arabia, however, old, outmoded and conventional methods including the now redundant Grammar Translation Method are followed. The result is that EFL learners are barely equipped in the use of English in real life situations. This study is not only an analysis of the current situation but also a resource for the teachers who wish to include films in their EFL classrooms. Empirically, the study proves, albeit with a small sample of fifty students, that learning outcomes improve drastically with the use of films in English language teaching.
\end{abstract}

Keywords: Film/Video; Communicative skills; Pedagogy; Paralanguage; Real life use of English

\section{Introduction}

Contrary to the traditional approaches to EFL teaching-learning from Grammar Translation to Total Response Theory, technology in today's world presents innumerable opportunities for the same for teachers as well as learners. Greater inclusion of audio-visual aids at all levels of language teaching lead to better language outcomes for the reason that learners are able to better comprehend language when exposed to it in a real context. For example, watching a character shop for things in all English environments will certainly lead to better learning than being taught the same theoretically in the language classroom. The facilitating factors, needless to say, are availability or access to Television, Videoequipment and computers. In some developing countries like India, Education Commissions as early as the 1990's realized the significance of these aids and introduced audio cassettes, videos and movies as a back up to literature. The results turned out to be so encouraging that now school books, not only in English but many other theoretical subjects such as Geography and History come equipped with relevant DVD's. Kikuchi (1997) says that teachers of languages have frequently resorted to audio-visual aids and equipment for more effective teaching in classes. Similar views have been expressed by Canning Wilson (2000); Kothari and Pandey and Meskill (1996); Ryan (1998); and Weyer (1999). Paralinguistic communication (comprising 38\% of total communication) too is best learnt through these especially in an EFL environment where exposure to the language is limited to classroom input. We all agree that language is a distinctly human endowment deeply rooted in culture. It is believed that Video presents authentic language along with cultural information about the speakers of English.

Robin (2007) stated that, for many years, the generally held view on the audio-comprehension had been that both the target language captions and the native language sub-titles were anathema to developing listening comprehension. However, this popular view has not so far been tested to the desired extent. The present study is, therefore, an effort to fill that gap.

\section{Why the short film?}

There are a good number of reasons why the short film has acquired its current status as an effective tool in the EFL classroom. Of course, student exposure to technology and its availability and portability (as in mobile phones) is one primary contributing factor. Some others are stated here.

Success in the language classroom is a factor of learners' motivation level. An environment that is both enjoyable and learner centred will certainly appeal to the EFL learners and lead to higher learning outcomes.

Films closely portray the society and vice versa. Sociologists aver that this is the reason why cinema has exerted an undeniable influence on the society. If language is to be learnt in a context, we cannot provide a better channel to our learners than the short film. Films make the process of language learning more entertaining and enjoyable, and, additionally, takes out the rut from the teacher's routine teaching. A motivated teacher who looks forward to being with 
the learners will certainly be able to achieve much more than in a conventional setting. The second reason why films are motivating tools in teaching English language is: Films provide authentic and varied language usage.

Examples of English used in 'real' situations outside the classroom are provided dramatically by the films. Films provide interactive language more particularly, and that interactive language is the language of real-life conversation; the learners are acquainted with it. The students are exposed to natural expressions by the Film. It uses and teaches the natural flow of speech. The learners of English learn it as second or foreign language and most of them are not living in an English-speaking environment. In such a situation, it is perhaps only film and television that can provide learners with this input of real-life language.

Films provide opportunity for a total immersion experience which is not possible to simulate in an EFL environment. The audio-visual aspect of the film is complemented by involvement of the EI (Emotional Intelligence) making the language learning experience holistic. Dynamics of conversation are well covered by the film and this is a situation that is missing in classroom teaching. The learners are thereby prompted to see the visual supports such as facial expressions and gestures (body language) simultaneously. These visual clues serve as support to comprehend the verbal message and simultaneously provide a focus of attention.

Films provide a wide scope for the primary language skills viz. listening, speaking, reading and writing individually and in combination. Let us take an example: a whole film or its sequence can be used with desired advantage to practice listening and reading. It can also serve as a model for speaking and writing. A film can act not only as a springboard for follow-up tasks such as (i) discussions; (ii) debates on social issues; (iii) role plays; (iv) activities like reconstructing a dialogue or summarizing but also it is possible in the process to bring further variety to the language learning classroom by screening different types of films like (a) feature-length films; (b) short sequence films; (c) short films; and (d) advertisements. Usable vocabulary and possible sentence structures are available to the learners while watching films.

Finally, learners can be encouraged to shoot short clips where they may demonstrate effective English language use.

\section{What the Experts say and Creating a Resource Pool for Teachers}

Berk (2009) concluded a scientific study on the working of 'Videos and the Brain'. He explains the process a video undergoes in a student's brain facilitating his learning. This process covers four core intelligences: Verbal/linguistic intelligence; Visual/spatial intelligence; Musical/rhythmic intelligence; and emotional intelligence. These are further complemented by the (a) role played by the left and right hemispheres of the brain; (b) triune brain; and (c ) brain wave frequencies. Berk has drawn video brain conclusions in his 'in-depth' study. The first three core intelligences mentioned above are explained below:

Verbal Linguistic Intelligence: Learning is done by reading, writing, speaking and listening as well as by debating, discussing and playing word-games.

Visual/Spatial Intelligence: It facilitates learning by seeing, imagining, drawing, sculpting, painting, decorating, designing, graphics and architecture, coordinating colour, and creating mental pictures.

Musical/Rhythmic Intelligence: This intelligence facilitates students' learning by singing, humming, listening to music, composing, keeping time, performing and recognizing rhythm.

These intelligences are part of that unique profile of strong and weak intelligences that every student possesses; these are not equally distributed among all students. Therefore, some are slow learners and some are fast learners, and all of them learn in varying degrees.

Zull (2002) says that Neuroscience research has confirmed the physical differences in the neuronal networks of each student's brain. Therefore, language and other instructors can work with what a student brings to the class room; differences in learning process, extent and manner as well as degree of memory and application to the teaching.

Gardner (2000) and Veenema \& Gardner (1996) add that this 'pluralistic view of the mind' permits faculty-members to think of exposing their students to a wide range of learning strategies. Every student thus draws upon 4 to 6 intelligences that allow him/her to use his/her own strength-intelligence as well as to convert his/her weak intelligences into strong ones. The scholars stress that Videos can, they opine, tap verbal/linguist and visual/spatial and even musical/rhythmic intelligences.

For teacher support, a well-researched and documented resource can be found with Kieran Donaghy (2014). He suggests that many websites and blogs provide detailed and properly structured lessons and well-designed lesson plans to draw upon. These lesson plans are prepared on film and television clips as well as short films and viral videos. These serve as dependable material and thus save a teacher's time in doing this collection and edit-work. He has also indicated some of his favourite pieces. These are:

(i) 'All at C', which he claims to be a superb blog by two authors, namely Steve Muir and Tom Spain. Their blog supplies lesson plans which are based on short videos, especially based on clips from television series. The blog has rendered service to a teacher who is spared of his time collecting such clips and editing them;

(ii) Lessonstream by Jamie Keddie who is stated by Steve et al as pioneer in using video for teaching of language. Keddie's website is claimed to be rich store-house in creative and imaginative lesson plans which are based on short videos; 
(iii) Viral ELT, a blog by Ian James that is dedicated for accessing and exploiting viral videos concerned with teaching of language; (iv) Film English, an adequate resource site of Kieran Donaghy (2014) which contains over 120 language teaching lesson plans, all based on short films;

(iv) Film Guides: There are several sites now-a-days in which high quality film guides are available, saving many hours of intelligent labour of teachers to prepare lesson plans for language teaching through films/videos.

(v) ESL Notes: Raymond Weschler has created this resource site containing more than 200 film guides with details. Each guide in this is a detailed synopsis of a popular classic film or a contemporary one, containing also full glossary of vocabulary along with expressions that the students come across in the film being viewed;

(vi) Film in Language Teaching Association (FILTA): It is an association having membership of teachers of language, educators of films and those engaged in research. It contains and supplies film guides to teachers, useful to them in language teaching class rooms;

(vii)Film Club: It is a charity in the United Kingdom. It provides children as well as the young people an opportunity to watch, discuss and review films; the Film Club also supplies hundreds of pedagogically sound film guides for free;

(viii) Film Education: It is a website. It produces well-structured and attractive film guides for a wide range of language teaching films;

(ix) Short Films: Due to digital revolution, it has become easy to create moving images. The work has been facilitated by mobile devices with large scale acceptance. Digital technology has made it easier to capture and edit video. Further facilitation factor is the availability of video distribution sites such as 'You Tube' and 'Vimeo'. These factors have led to explosion in the area of production of short films and making them available too. There is, however, difficulty being experienced by the teachers in choosing high quality short films for using them in the language teaching class rooms out of the ever increasing basket of such films in the market/websites.

Short creative films may be found at Vimeo Staff Picks (a channel containing selected high quality short films, selected by the staff at Vimeo); Future Shorts (a You Tube channel stocked with hundreds of short films with different narratives duly structured); and Short of the Week (a website dedicated to facilitating finding the best short films available online).

Films are an active part of ELT in many ESL and EFL countries, especially in the third world. In some of these countries, English is taught as the Second Language, being introduced alongside the mother tongue and also as the medium of instruction; while in some regions English is introduced a few years after the learners begin school, as a language to be learnt while the medium of instruction remains the mother tongue. Interestingly, teaching through films is popular in these cultures not just with the teachers but also the students. In fact, short videos produced by the BCD (British Council Division) are a great source of exposure. Moreover the ready availability of Smart Boards which are nothing but E-equipped classrooms can contribute immensely to education in general and ELT in particular. Across board, two sites viz. Bombay Clips and Clip Fair are used as regular class activities in many ESL classrooms. Other popular sites are English Central which focuses on pronunciation drills which can be undertaken in language laboratories that also provide the learners with immediate feedback. Learn English Teens Film UK provides exercises in various English skills. At Animated Movies learners can create and post their own short animation movies. Needless to say, language laboratories can be rigorously used for improving the learners' speaking skills.

\section{Present Study}

The present study is descriptive and analytical. The population comprised undergrad students of all academic streams and random sampling method was used for constituting a sample of 50 students learning English as Second/Foreign language. Ten percent of the sample quantity constituted girl-students. Analysis was done manually as the sample size was not large.

\subsection{The research questions include}

1) Is contextualized film-showing with or without subtitles based on a multi-sensory approach a more effective intervention than Dual Code Model and reading only the text and undertaking comprehension in EFL learning in the class room?

2) What is the performance difference in learning proficiency of EFL between students learning with the help of films and those learning by traditional methods in regard to comprehension, memory, word power, accent, pronunciation and recognition of idea or theme in the content?

The broad objectives were to find out the efficacy of using films (videos) for teaching/learning English in colleges in KSA; singling out the preference of English language learners as regards use of films/videos in the classrooms for development of listening and speaking skills; and to get teacher feedback regarding use of films with contextual comprehension in teaching EFL in the class rooms for development of listening and speaking skills.

\section{Findings of the Study}

Two groups ' $A$ ' and ' $B$ ' comprising twenty five students each were formed. Group ' $A$ ' was the experimental group with instructions to focus on comprehension, pronunciation, word recognition, and accent in the films (videos) shown to them. The second group 'B', was taught by the method already being followed. The two Groups were requested not to share their experiences. 
The teaching content chosen was similar for both the Groups of English learning students. These included students in their fourth semester of the BA Programme for which multimedia parallels were also available. Entry point test was administered and scores kept confidential (secret). The experiment spanned over a period of four months. End-point test was given, identical for both the Groups, concurrently.

The end point test included pair activities ( 25 points) to simulate content they were exposed to, play acting in group (40 points), writing dialogues (20 points) for the characters of the films but in hypothetical situations, preparing a script (15 points) for one of the items and a theoretical exam (worth 50 points to test general comprehension and gleaning word meanings from the context). The total evaluation was for 150 marks.

The average total score of Group A was 22 as compared to Group B at 11: The difference is remarkable. The groups showed near parity in the Play Acting activity though Group A was still slightly better at 33 as compared to 31 of Group B. In Dialogue Writing, Group A scored a remarkable high of 18 average points while Group B remained at 6. Similarly, in Script Writing, Group A came higher with an average of 12 as compared to Group B's 5. In General Comprehension and Gleaning of Word Meaning, Group A showed an average performance of 45 while Group B scored an average of 27 points. It may be noted here that the theoretical exam is on the same pattern as the learners are well exposed to in their regular classes. Thus, in all the components the experimental Group A performed better than Group B.

\section{Conclusion}

To conclude the study, a Likert Scale questionnaire was administered thrice to the students. In this scale, the rating option available is 1-5 where one means very poor or low rating and 5 means good or high. The questionnaire was administered at the beginning, middle and concluding stages of the study. The ten questions were as follows:

1. I look forward to my English class.

2. During the class I feel lost and bored.

3. The teacher is enthusiastic to conduct the class.

4. I wait for the class to end.

5. I talk to my friend during the class.

6. I feel I am learning useful language items in the class.

7. I would like this method to be followed in my other subjects.

8. I often feel I am wasting my time in the English class.

9. I would rather study some other subject than English.

10. I am happy I opted for English.

Whereas the responses for both the groups showed parity at the beginning of the study, the readings changed for Group $\mathrm{A}$ in the middle of the course with the analysis showing that the students felt positively disposed towards the new methodology. However, Group B still showed similar or same responses at this second administration. In the third attempt though, Group A were certain of being benefitted from watching films while Group B showed similar responses as in attempts one and two.

\subsection{Suggestions and Recommendations}

Here are some pedagogical suggestions that the teacher can incorporate into their daily English Language Class:

1) Encourage students to visit the sites named here. Follow it up with questions about the movies seen by them.

2) Invent exercises in phonetics, semantics, and syntax based on the films screened.

3) Encourage multi-dimensional exercises such as asking the students to produce short films on language use.

4) Do listening activities: After watching a movie, listeners can demonstrate comprehension by: (a) comparing; (b) discriminating; (c) predicting; (d) sequencing; (e) classifying; (f) transferring information, etc. unlike other listening activities, stories are often repeated, but never in exactly the same words.

5) Take the students to the language laboratory and screen movies there. Follow it up with speaking exercises.

6) Do oral activities: These are (a) Choral reading; (b) story fill-in; (c) add-on stories; (d) building a tale from key words, etc. Discussion topics can be taken from the movie's themes; students can retell their favorite movie.

7) Undertake written activities based on movies: Screen only half a movie and ask the students to write a script for the other half.

8) Ask students to design promotional materials for their favorite movie out of the ones screened by the teacher.

9) Create your own workbook with exercises based on movies and documentaries that you intend to show the learners.

\section{References}

Berk, R.A. 2009. Multimedia teaching with video clips: TV, movies, YouTube, and MTVU in the college classroom. International Journal of Technology in Teaching and Learning 5(1), 1-21. 


Donaghy, K. (2014). How can film help you teach or learn English? Accessed/Retrieved from
https://www.britishcouncil.org/voices-magazine/how-can-film-help-you-teach-or-learn-english

Gardner, H. (2000). Can technology exploit our many ways of knowing? In D. T. Gordon (Ed.), The digital classroom: How technology is changing the way we teach and learn (pp. 32-35). Cambridge, MA: President and Fellows of Harvard College.

Kikuchi, T. (1997). A review of research on the educational use of English captioned materials in Japan (Accessed/Retrieved from http://www.robon.org/gary/captioning/Kikuchi. html)

Kothari, B,. Pandey, A, and Chudgar, A. R. (2004). Reading out of the Idiot Box; same language subtitling on television in India. Information Technologies and International Development. 2.1, 23-44

Meskill, C. (1996). Listening Skills through Mass Media. Journal of Educational Multimedia and Hypermedia, 5.2, 179201

Richards, J. C. \& Gordon, D. B. (2004). New Interchange Intro: Video Teacher's Guide. New York: Cambridge University Press

Robin, R. (2007). Commentary: Learner-based Listening and Technological Authenticity. Language Learning and Technology, 11(1), 109-115

Ryan, S. (1998). Using Films to develop learner-motivation. The Internet TESL. Journal, 4(11).Accessed/Retrieved from http://iteslj.org/Articles/Ryan Films. Html

Veenema, S., \& Gardner, H. (1996). Multimedia and multiple intelligences. The American Prospect, Nov.-Dec. (29), 69-75.

Weyer, J. R. (1990). The effect of authentic video on communicative competence. The Modern Language Journal. 83 (3), 339-349

Wilson, C. (2000). Practical aspects of using video in the foreign language classroom. The Internet TESL Journal 6(11), Nov. Retrieved from http://iteslj.orglArticies/Canning-Video.html.

Zull, J. E. (2002). The art of changing the brain: Enriching the practice of teaching by exploring the biology of learning. Sterling, VA: Stylus. 